\title{
SISTEM PENDUKUNG KEPUTUSAN PENETUAN PERAWATAN BAGI PESERTA BPJS KESEHATAN DENGAN METODE SIMPLE ADDITIVE WEIGHTING
}

\author{
Yulia Darnita ${ }^{1}$, Muntahanah ${ }^{2}$ \\ ${ }^{1,2}$ Program Studi Teknik Informatika, Fakultas Teknik, Universitas Muhammadiyah Bengkulu \\ Jl. Bali PO. BOX 118 Kota Bengkulu 38119 Indonesia \\ ${ }^{1}$ yuliadarnita@gmail.com \\ ${ }^{2}$ hanna. umbegmail.com
}

\begin{abstract}
Abstrak: Badan Penyelenggara Jaminan Sosial Kesehatan (BPJS Kesehatan) dalam penentuan kelas perawatan pada saat ini masih menggunakan sistem manual dengan cara peserta memilih sendiri kelas perawatan mana yang harus dipilih. Sedangkan kelas perawatan yang harus dipilih tidak sesuai dengan kebijakan yang telah ditentukan oleh pihak BPJS Kesehatan. Terkadang para peserta memilih kelas perawatan tidak sesuai dengan kemampuan para peserta. Mereka lebih memilih kelas yang rendah dikarenakan bayaran tiap bulannya rendah yang semestinya mereka mampu memilih kelas perawatan yang lebih tinggi berdasarkan kriteria dari pekerjaannya. Pada ketentuan tersebut maka sistem pendukung keputusan ini akan membantu BPJS Kesehatan dalam menentukan kelas perawatan bagi para peserta dengan melihat kriteria dari pekerjaan para peserta sehingga para peserta tidak bisa memilih sendiri kelas perawatannya. Sistem dirancang dengan menggunakan metode Simple Additive Weighting (SAW) karena mampu menyeleksi alternatif terbaik dari sejumlah alternatif. untuk efisiensi waktu dalam menentukan kelas peserta. Berdasarkan hasil pengujian sistem dapat diambil kesimpulan sebagai berikut : Pada sistem pendukung keputusan ini diperoleh 3 kelas perawatan yang dapat ditentukan dengan kriteria pada setiap kelas perawatan berdasarkan sub kriteria berupa Non PBI dan PBI, metode Simple Additive Weighting ini mempunyai kelemahan dalam perubahan kriteria yang ada sehingga harus menambah penilaian normalisasi. Adapun kelebihannya adalah metode ini dapat mempermudah dalam penentuan solusi.

Kata Kunci: Perawatan, Peserta, Asuransi, Simple Additive Weighting.
\end{abstract}

Abstract: The Health Insurance Administering Body (BPJS Kesehatan) in the determination of the treatment class at this time still uses the manual system by the way the participants choose themselves which treatment class should be selected. While the treatment class that must be selected does not comply with the policy that has been determined by the BPJS Health. Some times the participants choose the treatment class does not match the ability of the participants. They prefer low classes due to low monthly payments that they should be able to choose a higher care class based on the criteria of their work. In these provisions the decision support system will assist BPJS Health in determining the class of care for the participants by looking at the criteria of the job participants so that participants can not choose their own treatment class. The system is designed using Simple Additive Weighting (SAW) method because it is able to select the best alternative from a number of alternatives. for time efficiency in determining the class of participants. Based on the results of system testing can be concluded as follows: In this decision support system obtained 3 classes of treatment that can be determined by the criteria in each class of care based on sub-criteria of non PBI and PBI, Simple Additive Weighting method has a weakness in changing the criteria so that should increase the assessment of normalization. The advantages are this method can be easier in determining the solution.

Keywords: Care, Participants, Insurance, Simple Additive Weightin 
Jurnal Pseudocode, Volume VI Nomor 1, Februari 2019, ISSN 2355-5920, e-ISSN 2655-1845 www.ejournal.unib.ac.id/index.php/pseudocode

\section{Pendahuluan}

Pada tahun 1986, WHO, dalam Piagam Ottawa untuk Promosi Kesehatan, mengatakan bahwa pengertian kesehatan adalah "sumber daya bagi kehidupan sehari-hari, bukan tujuan hidup Kesehatan adalah konsep positif menekankan sumber daya sosial dan pribadi, serta kemampuan fisik. Kesehatan merupakan keadaan sejahtera dari badan, jiwa, dan sosial yang memungkinkan setiap orang hidup produktif secara sosial dan ekonomis.

Pemeliharaan kesehatan adalah upaya penaggulangan dan pencegahan gangguan kesehatan yang memerlukan pemeriksaan, pengobatan dan/ atau perawatan termasuk kehamilan dan persalinan.

Kesehatan merupakan hal yang utama bagi manusia. setiap individu dapat melakukan aktivitas sehari-hari dengan produktif dengan keadaan yang sehat. Saat sakit tentunya diperlukan biaya untuk berobat ke dokter atau membeli obat. Pemerintah Indonesia bertanggung jawab dalam memberikan jaminan perlindungan kesehatan dan fasilitas bagi masyarakat Indonesia sesuai dengan peraturan Presiden Nomor 28 tahun 2016 mengenai Jaminan Kesehatan, pada tanggal 1 Januari 2014 telah didirikan suatu Badan Penyelenggara Jaminan Sosial Kesehatan yang selaras dengan tujuan Organisasi Kesehatan Dunia dalam mengembangkan jaminan kesehatan untuk semua penduduk. BPJS kesehatan ini merupakan badan hukum yang dibentuk untuk menyelenggarakan program kesehatan (Peraturan BPJS Kesehatan Nomor 1 Tahun 2014) [1].

Semakin pesatnya perkembangan teknologi dewasa ini menuntut masyarakat untuk semakin cepat mendapatkan informasi. Untuk mencapai tujuan tersebut diperlukan teknologi informasi dalam pengolahan data. Pengolahan data yang baik akan menghasilkan informasi cepat, akurat dan dapat di percaya.

Informasi merupakan acuan utama untuk mengambil kebijakan perusahaan. Dalam hal ini mengenai kebijakan penentuan kelas perawatan peserta Badan Penyelenggara Jaminan Sosial Kesehatan (BPJS Kesehatan). Dalam penentuan kelas perawatan pada saat ini masih menggunakan sistem manual dengan cara peserta memilih sendiri kelas perawatan mana yang harus dipilih. Sedangkan kelas perawatan yang harus dipilih tidak sesuai dengan kebijakan yang telah ditentukan oleh pihak BPJS Kesehatan.

Pada ketentuan tersebut maka sistem pendukung keputusan ini akan membantu BPJS Kesehatan dalam menentukan kelas perawatan bagi para peserta dengan melihat kriteria dari pekerjaan para peserta sehingga para peserta tidak bisa memilih sendiri kelas perawatannya. Terkadang para peserta memilih kelas perawatan tidak sesuai dengan kemampuan para peserta. Mereka lebih memilih kelas yang rendah dikarenakan bayaran tiap bulannya rendah yang semestinya mereka mampu memilih kelas perawatan yang lebih tinggi berdasarkan kriteria dari pekerjaannya. Sistem dirancang dengan menggunakan metode Simple Additive Weighting (SAW) karena mampu menyeleksi alternatif terbaik dari sejumlah alternative. Untuk efisiensi waktu dalam menentukan kelas peserta BPJS Kesehatan diperlukan penggunaan system pendukung keputusan yang baik.

\section{LANDASAN TEORI}

\section{A. Sistem Pendukung Keputusan (SPK)}

Menurut Janner Simarmata, sistem pendukung keputusan adalah sistem penghasil informasi spesifik yang ditujukan untuk memecahkan suatu 
Jurnal Pseudocode, Volume V Nomor 2, September 2018, ISSN 2355-5920, e-ISSN 2655-1845 www.ejournal.unib.ac.id/index.php/pseudocode

masalah tertentu yang harus dipecahkan oleh manajer pada berbagai tingkatan. Sistem pendukung keputusan adalah suatu sistem informasi bebasis komputer yang menghasilkan berbagai alternatif keputusan untuk membantu manajemen dalam menangani berbagai permasalahan yang terstruktur ataupun tidak terstruktur dengan menggunakan data dan model. Kata berbasis komputer merupakan kata kunci, karena hampir tidak mungkin membangun SPK tanpa memanfaatkan komputer sebagai alat bantu, terutama untuk menyimpan data serta mengelola model [2].

\section{B. Kesehatan}

Kesehatan adalah keadaan sempurna, baik fisik, mental, maupun sosial, dan tidak hanya bebas dari penyakit dan cacat. Apa bila pada batasan yang terdahulu kesehatan itu hanya mencakup tiga dimensi atau aspek yakni: fisik, mental dan sosial, tetapi menurut Undang Undang No. 23 Tahun 1992, kesehatan mencakup 4 aspek, yakni: fisik (badan), mental ( jiwa), sosial dan ekonomi. [3] bahwa kesehatan adalah keadaan sejahtera dari badan, jiwa dan sosial yang memungkinkan setiap orang hidup produktif secara sosial".orang miskin juga berhak dalam mendapatkan pelayananan kesehatan.

\section{Badan Penyeleggara jaminan sosial (BPJS)}

Menurut UU no. 24 tahun 2011 tentang BPJS pasal 7 ayat (1) dan Ayat (2), pasal 9 ayat (1) dan UU. No. 40 Tahun 2011 Tentang SJSN, Pasal 1 Angka 8, Pasal 4 Dan Pasal 5 ayat (1)). Badan Penyeleggara jaminan sosial kesehatan (BPJS Kesehatan) adalah badan hukum publik yang bertanggung jawab kepada presiden dan berfungsi menyelenggarakan program jaminan kesehatan bagi seluruh penduduk Indonesia termasuk orang asing yang bekerja paling singkat 6 (enam) Bulan di Indonesia. Badan Usaha Milik Negara yang ditugaskan khusus oleh pemerintah untuk menyelenggarakan jaminan pemeliharaan kesehatan bagi seluruh rakyat Indonesia, terutama untuk Pegawai Negeri Sipil, Penerima Pensiun PNS dan TNI/POLRI, Veteran, Perintis Kemerdekaan beserta keluarganya dan Badan Usaha lainnya ataupun rakyat biasa.

BPJS Kesehatan bersama BPJS Ketenagakerjaan (dahulu bernama Jamsostek) merupakan program pemerintah dalam kesatuan Jaminan Kesehatan Nasional (JKN) yang diresmikan pada tanggal 31 Desember 2013. Untuk BPJS Kesehatan mulai beroperasi sejak tanggal 1 Januari 2014, sedangkan BPJS Ketenagakerjaan mulai beroperasi sejak 1 Juli 2014.[4].

D. Metode Simple Additive Weighting (SAW)

Metode Simple Additive Weighting (SAW) sering juga dikenal istilah metode penjumlahan terbobot. Konsep dasar metode SAW adalah mencari penjumlahan terbobot dari rating kinerja pada setiap alternatif pada semua atribut. Metode ino membutuhkan proses normalisasi matriks keputusan $X$ ke suatu skala yang dapat diperbandingkan dengan semua rating alternatif yang ada. Formula untuk melakukan normalisasi tersebut adalah sebagai berikut [5].

$$
r_{i j}=\left\{\begin{array}{c}
\frac{x_{i j}}{\operatorname{Max}_{i} x_{i j}} j i k a j \text { adalah atribut keuntungan } \\
\frac{\operatorname{Min}_{i} x_{i j}}{x_{i j}} \text { jika } j \text { adalah atribut biaya }
\end{array}\right\}
$$

Dimana:

$r i j=$ rating kinerja ternormalisasi dari alternatif $A i$ $(\mathrm{i}=, 2, \ldots, \mathrm{m})$

Maxi = nilai maksimum dari setiap baris dan

kolom.

Mini $=$ nilai minimum dari setiap baris dan kolom . 
Jurnal Pseudocode, Volume VI Nomor 1, Februari 2019, ISSN 2355-5920, e-ISSN 2655-1845 www.ejournal.unib.ac.id/index.php/pseudocode

$X i j=$ baris dan kolom dari matriks.

Beberapa langkah dalam penyelesaian metode Simple Additive Weight (SAW) adalah sebagai berikut:

1. Menentukan kriteria-kriteria yang dijadikan acuan dalam pendukung keputusan yaitu $\mathrm{C} i$.

2. Menentukan rating kecocokan setiap alternatif pada setiap kriteria.

3. Membuat matriks keputusan berdasarkan kriteria $(C i)$.

4. Kemudian melakukan normalisasi matriks berdasarkan persamaan yang disesuaikan dengan jenis atribut (atribut keuntungan maupun atribut biaya) sehingga diperoleh matriks ternormalisasi $R$.

5. Hasil akhir diperoleh dari proses perangkingan yaitu penjumlahan dari perkalian matriks ternormalisasi $\mathrm{R}$ dengan vector bobot sehingga diperoleh nilai terbesar yang dipilih sebagai alternatis terbaik $(A i)$ sebagi solusi.

\section{Metode PENELITIAN}

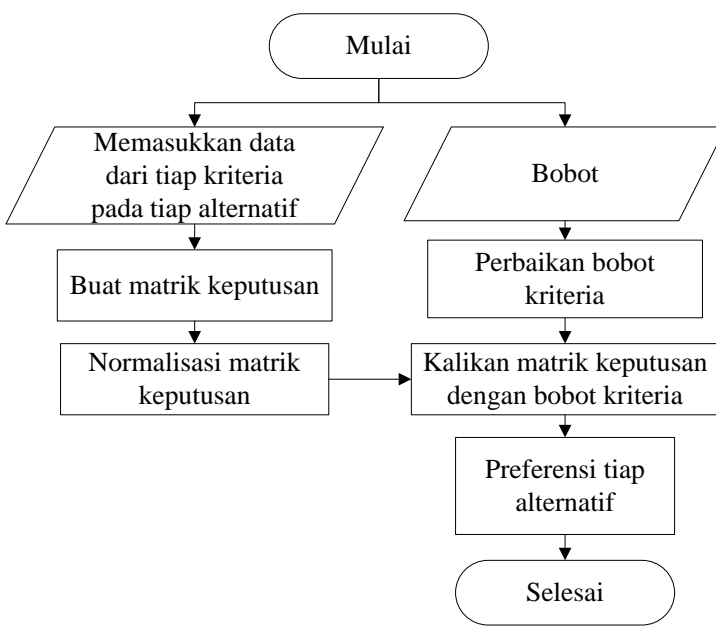

Gambar 1. Flowchart Metode Simple Additive Weight (SAW)

Di tahap ini kita mengisi bobot nilai dari suatu alternatif dengan kriteria yang telah dijabarkan tadi. Perlu diketahui nilai maksimal dari pembobotan ini adalah ' 100 '.
Tabel 1. Kriteria

\begin{tabular}{|c|c|c|c|c|c|}
\hline \multirow{2}{*}{$\begin{array}{c}\text { Calon } \\
\text { Pegawai }\end{array}$} & \multicolumn{5}{|c|}{ Kriteria } \\
\cline { 2 - 6 } & C1 & C2 & C3 & C4 & C5 \\
\hline A1 & 0,5 & 1 & 0,7 & 0,7 & 0,8 \\
\hline A2 & 0,8 & 0,7 & 1 & 0,5 & 1 \\
\hline A3 & 1 & 0,3 & 0,4 & 0,7 & 1 \\
\hline A4 & 0,2 & 1 & 0,5 & 0,9 & 0,7 \\
\hline A5 & 1 & 0,7 & 0,4 & 0,7 & 1 \\
\hline
\end{tabular}

\section{A. Pembobotan (w)}

Tabel 2. Tabel Kriteria dan Bobot

\begin{tabular}{|c|c|}
\hline Kriteria & Bobot \\
\hline $\mathrm{C} 1$ & 0,3 \\
\hline $\mathrm{C} 2$ & 0,2 \\
\hline $\mathrm{C} 3$ & 0,2 \\
\hline $\mathrm{C} 4$ & 0,15 \\
\hline $\mathrm{C} 5$ & 0,15 \\
\hline Total & 1 \\
\hline
\end{tabular}

Untuk normalisai nilai, jika faktor kriteria benefit digunakan rumusan:

$$
R_{i i}=\left(X_{i j} / \max \left\{X_{i j}\right\}\right)
$$

Dari kolom C1 nilai maksimalnya adalah ' 1 ', maka tiap baris dari kolom $\mathrm{C} 1$ dibagi oleh nilai maksimal kolom C1.

$$
\begin{aligned}
& \mathrm{R} 11=0,5 / 1=0,5 \\
& \mathrm{R} 21=0,8 / 1=0,8 \\
& \mathrm{R} 31=1 / 1=1 \\
& \mathrm{R} 41=0,2 / 1=0,2 \\
& \mathrm{R} 51=1 / 1=1
\end{aligned}
$$

Dari kolom C2 nilai maksimalnya adalah ' 1 ', maka tiap baris dari kolom C2 dibagi oleh nilai maksimal kolom C2.

$$
\begin{aligned}
& \mathrm{R} 12=1 / 1=1 \\
& \mathrm{R} 22=0,7 / 1=0,7 \\
& \mathrm{R} 32=0,3 / 1=0,3 \\
& \mathrm{R} 42=1 / 1=1 \\
& \mathrm{R} 52=0,7 / 1=0,7
\end{aligned}
$$

Dari kolom C3 nilai maksimalnya adalah '1', maka tiap baris dari kolom C3 dibagi oleh nilai maksimal kolom C3.

$$
\begin{aligned}
& \mathrm{R} 13=0,7 / 1=0,7 \\
& \mathrm{R} 23=1 / 1=1 \\
& \mathrm{R} 33=0,4 / 1=0,4
\end{aligned}
$$


Jurnal Pseudocode, Volume V Nomor 2, September 2018, ISSN 2355-5920, e-ISSN 2655-1845 www.ejournal.unib.ac.id/index.php/pseudocode

$$
\begin{aligned}
& \mathrm{R} 43=0,5 / 1=0,5 \\
& \mathrm{R} 53=0,4 / 1=0,4
\end{aligned}
$$

Untuk normalisai nilai, jika faktor kriteria cost digunakanan rumusan

$$
R_{i i}=\left(\min \left\{X_{i j}\right\} / X_{i j}\right)
$$

Dari kolom C4 nilai minimalnya adalah ' 0,5 ', maka tiap baris dari kolom C5 menjadi penyebut dari nilai maksimal kolom C5.

$$
\begin{aligned}
& \mathrm{R} 14=0,5 / 0,7=0,714 \\
& \mathrm{R} 24=0,5 / 0,5=1 \\
& \mathrm{R} 34=0,5 / 0,7=0,714 \\
& \mathrm{R} 44=0,5 / 0,9=0,556 \\
& \mathrm{R} 54=0,5 / 0,7=0,714
\end{aligned}
$$

Dari kolom C5 nilai minimalnya adalah ' 0,7 ', maka tiap baris dari kolom C5 menjadi penyebut dari nilai maksimal kolom C5.

$$
\begin{aligned}
& \mathrm{R} 15=0,7 / 0,8=0,875 \\
& \mathrm{R} 25=0,7 / 1=0,7 \\
& \mathrm{R} 35=0,7 / 1=0,7 \\
& \mathrm{R} 45=0,7 / 0,7=1 \\
& \mathrm{R} 55=0,7 / 1=0,7
\end{aligned}
$$

Masukan semua hasil penghitungan tersebut kedalam tabel yang kali ini disebut tabel faktor ternormalisasi.

\begin{tabular}{|c|c|c|c|c|c|}
\multicolumn{7}{c}{ Tabel 3. Tabel Faktor Ternomalisasi } \\
\hline 0,5 & 1 & 0,7 & 0,714 & 0,875 & \\
\hline 0,8 & 0,7 & 1 & 1 & 0,7 & \\
\hline 1 & 0,3 & 0,4 & 0,714 & 0,7 & \\
\hline 0,2 & 1 & 0,5 & 0,556 & 1 & \\
\hline 1 & 0,7 & 0,4 & 0,714 & 0,7 & \\
\hline
\end{tabular}

Setelah mendapat tabel seperti itu barulah kita mengalikan setiap kolom di tabel tersebut dengan bobot kriteria yang telah kita deklarasikan sebelumnya.

$$
\begin{aligned}
& \mathrm{A} 1=(0,5 * 0,3)+(1 * 0,2)+(0,7 * 0,2)+ \\
& (0,714 * 0,15)+(0,875 * 0,15) \\
& \mathrm{A} 1=0,72835 \\
& \mathrm{~A} 2=(0,8 * 0,3)+(0,7 * 0,2)+(1 * 0,2)+ \\
& (1 * 0,15)+(0,7 * 0,15)
\end{aligned}
$$

$$
\begin{aligned}
& \text { A2 }=0,835 \\
& \text { A3 }=(1 * 0,3)+(0,3 * 0,2)+(0,4 * 0,2)+ \\
& (0,714 * 0,15)+(0,7 * 0,15) \\
& \text { A3 }=0,6521 \\
& \text { A4 }=(0,2 * 0,3)+(1 * 0,2)+(0,5 * 0,2)+ \\
& (0,556 * 0,15)+(1 * 0,15) \\
& \text { A4 }=0,5934 \\
& \text { A5 }=(1 * 0,3)+(0,7 * 0,2)+(0,4 * 0,2)+ \\
& (0,714 * 0,15)+(0,7 * 0,15) \\
& \text { A5 }=0,7321
\end{aligned}
$$

perbandingan nilai akhir maka didapatkan nilai sebagai berikut.

$$
\begin{aligned}
& \mathrm{A} 1=0,72835 \\
& \mathrm{~A} 2=0,835 \\
& \mathrm{~A} 3=0,6521 \\
& \mathrm{~A} 4=0,5934 \\
& \mathrm{~A} 5=0,7321
\end{aligned}
$$

\section{HASIL DAN PEMBAHASAN}

A. Hasil

1. Menu Login

Menu Login digunakan untuk mengakses sistem. Menu ini berguna untuk dapat masuk ke dalam halaman berikutnya dan dapat digunakan user. Menu Login dapat dilihat pada gambar di bawah ini sebagai berikut:

\begin{tabular}{|l|l|l|}
\hline & & \\
\hline
\end{tabular}

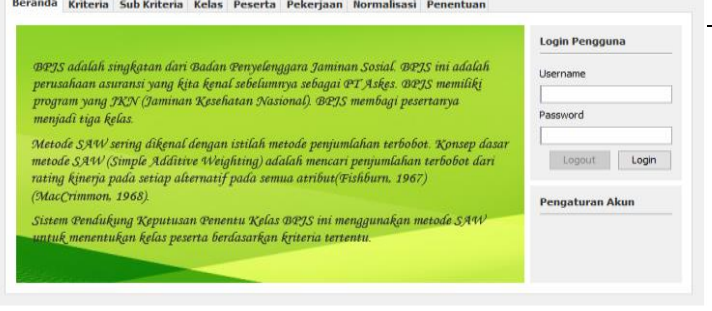

Gambar 2. Menu Login

\section{Menu Kriteria}

Menu kriteria menunjukkan apa saja kriteria dalam menentukan kelas perawatan berdasarkan iuran, pekerjaan, jenis pekerjaan, golongan dan gaji. Pada 
Jurnal Pseudocode, Volume VI Nomor 1, Februari 2019, ISSN 2355-5920, e-ISSN 2655-1845

www.ejournal.unib.ac.id/index.php/pseudocode

setiap kriteria akan diberi penilaian sehingga akan mempermudah dalam melakukan proses penentuan kelas perawatan yang sesuai dengan kemampuan masing-masing.

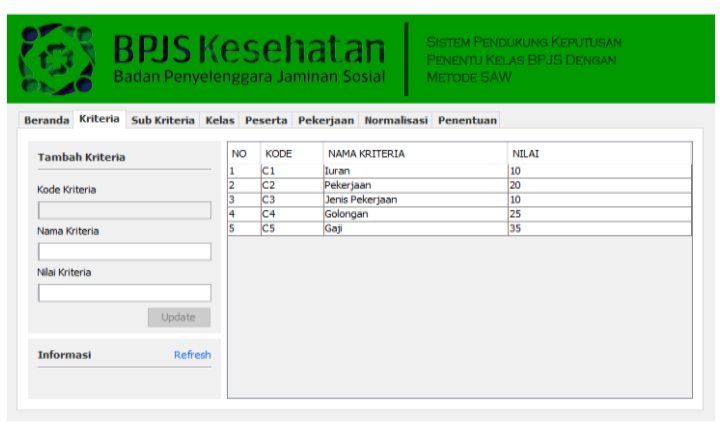

Gambar 3. Menu Kriteria

\section{Menu Sub Kriteria}

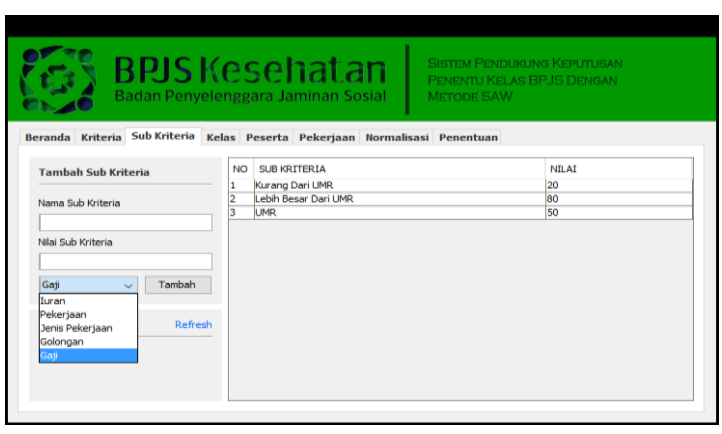

Gambar 4. Menu Sub Kriteria

Pada menu sub kriteria terdapat dua, yaitu Penerima bantuan iuran (PBI) dan non penerima bantuan iuran (Non PBI). Pada warga penerima PBI ini akan dibantu oleh pemerintah sedangkan non PBI akan melakukan iuran sendiri. Maka dari itu dalam memilih kelas perawatan maka harus ditentukan sub kriterianya.

\section{Menu Kelas Perawatan}

Pada menu kelas perawatan ini akan di tentukan kelas dengn melihat kriteria masing-masing kelas. Pada kelas 1 dan kelas 2 merupakan Non PBI dengan melihat kriteria pada pekerjaan, jenis pekerjaan, golongan dan gaji sedangkan pada kelas 3 merupakan PBI. Setelah menentukan kelas perawatan maka akan ditentukan nilai ketentuan pada masing-masing kelas. Sehingga akan lebih mempermudah dalam penghitungan metode SAW.

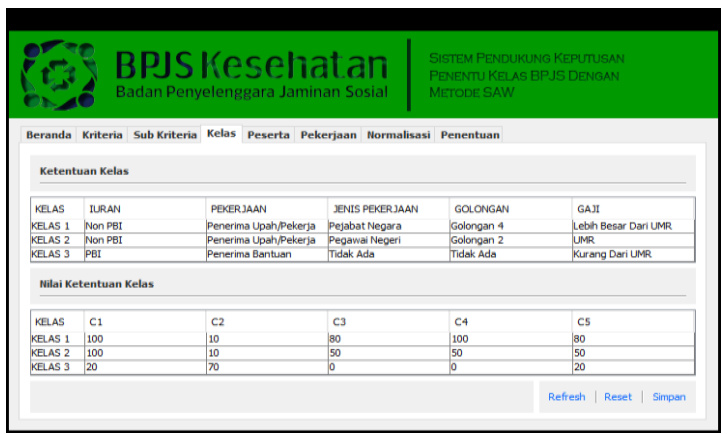

Gambar 5. Menu Kelas Perawatan

\section{Menu Input Peserta}

Pada menu input peserta ini berguna untuk memasukan calon peserta yang akan menentukan kelas perawatan, seperti pada Gambar 6 di bawah ini.

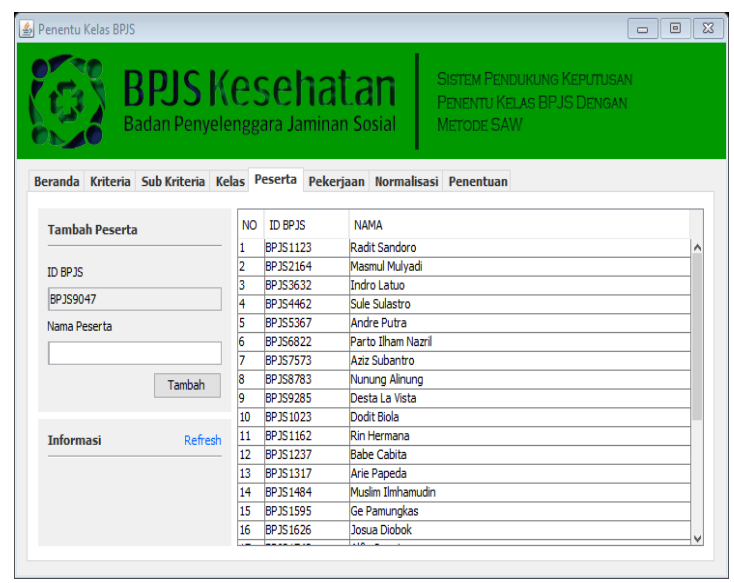

Gambar 6. Menu Input Peserta

6. Menu Input Pekerjaan

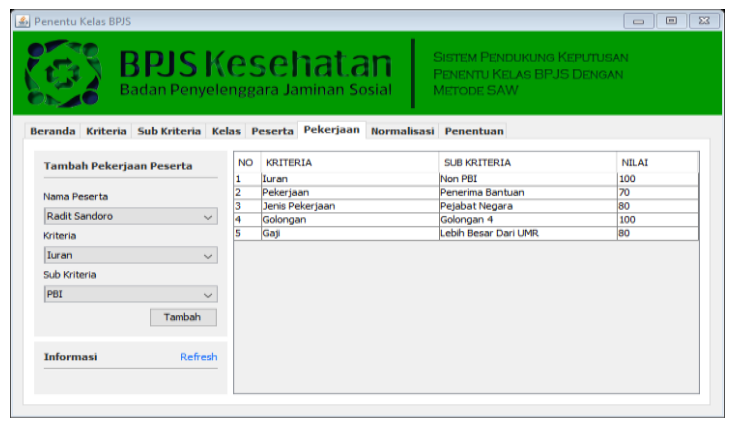

Gambar 7. Menu Input Pekerjaan

\section{Menu Normalisasi}

Menu normalisasi merupakan normalisasi pada metode SAW yang telah dilakukan pemilihan 
Jurnal Pseudocode, Volume V Nomor 2, September 2018, ISSN 2355-5920, e-ISSN 2655-1845 www.ejournal.unib.ac.id/index.php/pseudocode

kriteria pada setiap kelas perawatan. Sehingga akan mempermudah penentuan kelas yang sesuai dengan kriteria para peserta.

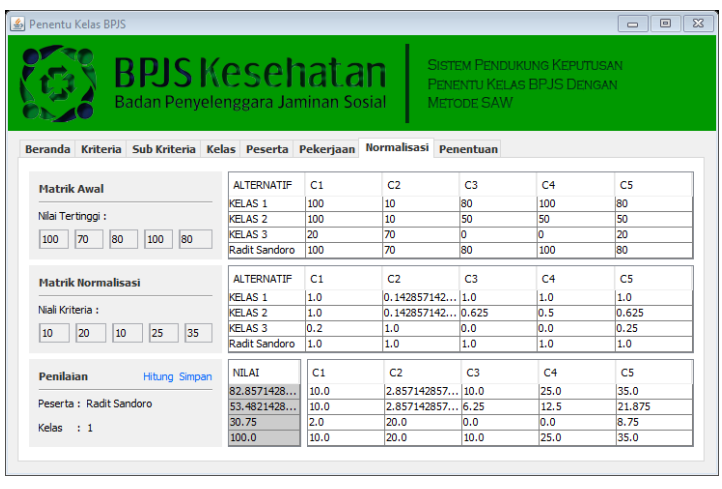

Gambar 8. Menu Normalisasi

8. Menu Penentuan

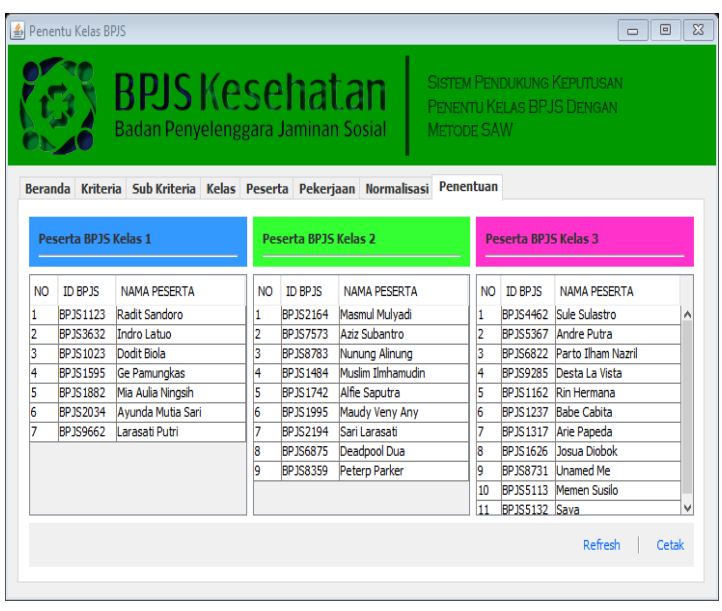

Gambar 9. Menu Penentuan

Setelah melakukan semua proses maka akan dapat ditentukan kelas masing-masing perawatan berdasarkan kriteria yang telah ada. Seperti pada Gambar 9 di atas telah dilakukan penentuan berdasarkan kelas masing-masing dan dapat dicetak untuk melakukan pengarsipan.

\section{B. Pembahasan}

Dalam kasus yang diambil di Rumah Sakit Umum Daerah M. Yunus Provinsi Bengkulu dengan kriteria penilaian meliputi Iuran, pekerjaan, jenis pekerjaan, golongan dan gaji yang didalam sub kriteria itu memiliki bobot masing-masing, maka dapat diasumsikan setiap bobotnya dengan nilai.

\begin{tabular}{|c|c|c|}
\multicolumn{3}{|c}{ Tabel 4. Bobot } \\
\hline Bobot Kriteria & Nama Kriteria & Nilai Kriteria \\
\hline C1 & Iuran & 10 \\
\hline C2 & Pekerjaan & 20 \\
\hline C 3 & Jenis Pekerjaan & 10 \\
\hline C 5 & Golongan & 25 \\
\hline C5 & Gaji & 35 \\
\hline
\end{tabular}

Berdasarkan data pada tabel di atas dirincikan bahwa dalam menggunakan angka puluhan hingga nilai total dari kriteria adalah 100. Beberapa kriteria digunakan sebagai bahan pertimbangan untuk mengambil keputusan, yaitu:

Tabel 5. Tabel Nilai Per Kriteria

\begin{tabular}{|c|c|c|}
\hline Kriteria & Kriteria Peserta & Nilai \\
\hline & PBI & 20 \\
\hline Iuran & Non PBI & 100 \\
\hline \multirow{4}{*}{ Pekerjaan } & Penerima Upah/Pekerja & 10 \\
\hline & Bukan Penerima Upah & 20 \\
\hline & Bukan Pekerja & 30 \\
\hline & Penerima Bantuan & 70 \\
\hline \multirow{12}{*}{$\begin{array}{c}\text { Jenis } \\
\text { Pekerjaan }\end{array}$} & Tidak Ada & 0 \\
\hline & TNI & 40 \\
\hline & Polri & 40 \\
\hline & Pegawai Swasta & 40 \\
\hline & Pekerja Mandiri & 40 \\
\hline & Pemberi Kerja & 40 \\
\hline & $\begin{array}{c}\text { Pegawai Pemerintah Non } \\
\text { Pegawai Negeri }\end{array}$ & 50 \\
\hline & Penerima Pensiun & 60 \\
\hline & Investor & 70 \\
\hline & Pejabat Negara & 80 \\
\hline & Veteran & 80 \\
\hline & Perintis Kemerdekaan & 80 \\
\hline \multirow{5}{*}{ Golongan } & Golongan 1 & 30 \\
\hline & Golongan 2 & 50 \\
\hline & Golongan 3 & 60 \\
\hline & Golongan 4 & 100 \\
\hline & Tidak ada & 0 \\
\hline \multirow{3}{*}{ Gaji } & Kurang dari UMR & 20 \\
\hline & Lebih Besar dari UMR & 80 \\
\hline & UMR & 50 \\
\hline
\end{tabular}

Data ini nantinya akan digunakan untuk mendapatkan nilai dari kriteria masing-masing peserta sebagai data acuan menentukan kelas BPJS. Pengguna memilih sub kriteria sesuai data peserta BPJS, misalnya:

Peserta BPJS memiliki:

1. Iuran

: PBI

2. Pekerjaan :Penerima Upah/Pekerja

3. Jenis Pekerjaan : Pegawai Negeri

4. Golongan : Golongan 2

5. Gaji : UMR 
Jurnal Pseudocode, Volume VI Nomor 1, Februari 2019, ISSN 2355-5920, e-ISSN 2655-1845 www.ejournal.unib.ac.id/index.php/pseudocode

Maka nilai kriteria peserta BPJS tersebut adalah: $20,10,50,50,50$.

Penentuan kelas beserta nilai masing-masing kriteria dari kelas bertujuan sebagai data pendukung yang mana nantinya akan di perhitungkan dan di bandingkan dengan nilai peserta BPJS dengan metode SAW sesuai metode yang di gunakan penulis pada tugas akhir ini. Data nilai kelas tersebut lebih rincinya dapat dilihat pada tabel di bawah ini:

Tabel 6. Nilai Kelas Perawatan

\begin{tabular}{|c|c|c|c|}
\hline Kelas & Kriteria & Sub Kriteria & Nilai \\
\hline \multirow{5}{*}{$\begin{array}{c}\text { Kelas } \\
1\end{array}$} & Iuran & Non PBI & 100 \\
\hline & Pekerjaan & $\begin{array}{l}\text { Penerima } \\
\text { Upah/Pekerja }\end{array}$ & 10 \\
\hline & Jenis Pekerjaan & Pejabat Negara & 80 \\
\hline & Golongan & Golongan 4 & 100 \\
\hline & Gaji & Lebih Dari UMR & 80 \\
\hline \multirow{5}{*}{$\begin{array}{c}\text { Kelas } \\
2\end{array}$} & Iuran & Non PBI & 100 \\
\hline & Pekerjaan & $\begin{array}{l}\text { Penerima } \\
\text { Upah/Pekerja }\end{array}$ & 10 \\
\hline & Jenis Pekerjaan & Pegawai Negeri & 50 \\
\hline & Golongan & Golongan 2 & 50 \\
\hline & Gaji & UMR & 50 \\
\hline \multirow{5}{*}{$\begin{array}{c}\text { Kelas } \\
3\end{array}$} & Iuran & PBI & 20 \\
\hline & Pekerjaan & $\begin{array}{l}\text { Penerima } \\
\text { Bantuan }\end{array}$ & 70 \\
\hline & Jenis Pekerjaan & Tidak Ada & 0 \\
\hline & Golongan & Tidak Ada & 0 \\
\hline & Gaji & $\begin{array}{l}\text { Kurang Dari } \\
\text { UMR }\end{array}$ & 20 \\
\hline
\end{tabular}

Pada tahap ini seharusnya nama peserta BPJS beserta data-data kriteria telah diinputkan selanjutnya melakukan perhitungan (dengan metode SAW) dan normalisasi. Dalam hal ini peserta bernama Radit Sandoro memiliki data kriteria sebagai berikut:

Tabel 7. Data Kriteria

\begin{tabular}{|c|l|c|}
\hline Bobot Kriteria & Nama Kriteria & Nilai Kriteria \\
\hline C1 & Iuran & 10 \\
\hline C2 & Pekerjaan & 20 \\
\hline C3 & Jenis Pekerjaan & 10 \\
\hline C4 & Golongan & 25 \\
\hline C5 & Gaji & 35 \\
\hline
\end{tabular}

Berdasarkan tabel di atas jika dilakukan normalisasi dengan data kelas yang sebelumnya telah di tetapkan maka akan terlihat seperti berikut:

Tabel 8. Normalisasi

\begin{tabular}{|l|c|c|c|c|c|}
\hline \multicolumn{1}{|c|}{ Alternatif } & C1 & C2 & C3 & C4 & C5 \\
\hline Kelas 1 & 100 & 10 & 80 & 100 & 80 \\
\hline Kelas 2 & 100 & 10 & 50 & 50 & 50 \\
\hline Kelas 3 & 20 & 70 & 0 & 0 & 20 \\
\hline $\begin{array}{l}\text { Radit } \\
\text { Sandoro }\end{array}$ & 100 & 70 & 80 & 100 & 80 \\
\hline & 100 & 70 & 80 & 100 & 80 \\
\hline
\end{tabular}

Selanjutnya nilai masing-masing kriteria dibagi dengan nilai tertinggi dari masing-masing kriteria yang telah didapatkan hingga terlihat seperti di bawah ini:

Tabel 9. Nilai Tertinggi

\begin{tabular}{|c|c|c|c|c|}
\hline C1 & C2 & C3 & C4 & C5 \\
\hline 100 & 70 & 80 & 100 & 80 \\
\hline
\end{tabular}

Selanjutnya nilai masing-masing kriteria dibagi dengan nilai tertinggi dari masing-masing kriteria yang telah didapatkan hingga terlihat seperti di bawah ini:

Tabel 10. Alternatif

\begin{tabular}{|l|c|c|c|c|c|}
\hline \multicolumn{1}{|c|}{ Alternatif } & C1 & C2 & C3 & C4 & C5 \\
\hline Kelas 1 & 100 & 10 & 80 & 100 & 80 \\
\hline Kelas 2 & 100 & 10 & 50 & 50 & 50 \\
\hline Kelas 3 & 20 & 70 & 0 & 0 & 20 \\
\hline Radit Sandoro & 100 & 70 & 80 & 100 & 80 \\
\hline & 100 & 70 & 80 & 100 & 80 \\
\hline
\end{tabular}

C1 $100,100,20,100=1.0,1.0,0.2$,

$=\overline{100} 1.0$

C2 $10,10,70,70$

$=70$

C3 $80,50,0,80$

$=\overline{80}=1.0,0.625,0.0,1.0$

C4 $100,50,0,100=1.0,0.5,0.0$.

$=\overline{100} 1.0$

C5 $80,50,20,80=1.0,0.625,0.25$,

$=\overline{80} 1.0$ 
Jurnal Pseudocode, Volume V Nomor 2, September 2018, ISSN 2355-5920, e-ISSN 2655-1845 www.ejournal.unib.ac.id/index.php/pseudocode

Tabel 10. Alternatif

\begin{tabular}{|l|c|c|c|c|c|}
\hline Alternatif & C1 & C2 & C3 & C4 & C5 \\
\hline Kelas 1 & 1 & 0.14 & 1 & 1 & 1 \\
\hline Kelas 2 & 1 & 0.14 & 0.625 & 0.5 & 0.63 \\
\hline Kelas 3 & 0.2 & 1 & 0 & 0 & 0.25 \\
\hline Radit Sandoro & 1 & 1 & 1 & 1 & 1 \\
\hline & 100 & 70 & 80 & 100 & 80 \\
\hline
\end{tabular}

Lalu hasil pembagian dikali-kan dengan nilai ketetapan kriteria yang di awal telah ditentukan yakni $\mathrm{C} 1=10, \mathrm{C} 2=20, \mathrm{C} 3=10, \mathrm{C} 4=25, \mathrm{C} 5=35$.

$$
\begin{aligned}
& \mathrm{C} 1=(1.0,1.0,0.2,1.0) \times 10 \\
&=10.0,10.0,2.0,10.0 \\
& \mathrm{C} 2=(0.14,0.14,1.0,1.0) \times 20 \\
&=2.86,2.86,20.0,20.0 \\
& \mathrm{C} 3=(1.0,0.625,0.0,1.0) \times 10 \\
&=10.0,6.25,0.0,10.0 \\
& \mathrm{C} 4=(1.0,0.5,0.0,1.0) \times 25 \\
&=25.0,12.5,0.0,25.0 \\
& \mathrm{C} 5=(1.0,0.625,0.25,1.0) \times 35 \\
&=35.0,21.88,8.75,35.0
\end{aligned}
$$

Tabel 11. Alternatif

\begin{tabular}{|l|c|c|c|c|c|}
\hline Alternatif & C1 & C2 & C3 & C4 & C5 \\
\hline Kelas 1 & 10.0 & 2.86 & 10.0 & 25.0 & 35.0 \\
\hline Kelas 2 & 10.0 & 2.86 & 6.25 & 12.5 & 21.88 \\
\hline Kelas 3 & 2.0 & 20.0 & 0.0 & 0.0 & 8.75 \\
\hline Radit Sandoro & 10.0 & 20.0 & 10.0 & 25.0 & 35.0 \\
\hline
\end{tabular}

Setelah dikalikan dengan nilai kriteria kemudian nilai kriteria masing-masing alternatif tersebut dijumlahkan. Hasil penjumlahan merupakan nilai final dari setiap alternatif. Nilai tersebutlah yang akan menjadi penentu kelas peserta BPJS.

Jika nilai peserta BPJS sama dengan atau lebih besar dari nilai alternatif kelas 1, maka peserta BPJS tersebut merupakan anggota BPJS kelas 1. Jika nilai peserta BPJS lebih kecil atau sama dengan nilai alternatif kelas 2, maka peserta PBJS tersebut merupakan anggota BPJS kelas 3. Jika nilai peserta BPJS lebih besar atau sama dengan nilai alternatif kelas 2 dan nilai peserta BPJS tersebut lebih kecil dari nilai alternatif kelas 1, maka peserta BPJS tersebut meruakan anggota BPJS kelas 2.

Kelas $1=10.0+2.86+10.0+25.0+35.0$

$$
=82.86
$$

Kelas $2=10.0+2.86+6.25+12.5+21.88$

$$
=53.48
$$

Kelas $3=2.0+20.0+0.0+0.0+8.75$

$$
=30.75
$$

Radit Sandoro $=10.0+20.0+10.0+25.0+35.0$

$$
=100.0
$$

Dapat dilihat dari hasil penjumlahan di atas bahwa nilai alternatif dari peserta BPJS adalah 100.0 dan lebih tinggi dari pada nilai alternatif kelas 1, maka Radit Sandoro merupakan peserta BPJS kelas 1.

\section{KESIMPULAN DAN SARAN}

\section{A. Kesimpulan}

Berdasarkan hasil pengujian yang telah dapat disimpulkan sebagai berikut:

1. Pada sistem pendukung keputusan ini diperoleh 3 kelas perawatan yang dapat ditentukan dengan kriteria pada setiap kelas perawatan berdasarkan sub kriteria berupa Non PBI dan PBI.

2. Adapun kelemahan program ini adalah pada penambahan kriteria sehingga akan timbulnya sub kriteria. jika ada perubahan pada data yang ada. Aplikasi dibuat fleksibel sehingga dapat memungkinkan personal untuk dapat mengubah kriteria yang ada.

3. Pada Metode Simple Additive Weighting ini mempunyai kelemahan dalam perubahan kriteria yang ada sehingga harus menambah penilaian normalisasi. Adapun kelebihannya adalah metode ini dapat mempermudah dalam penentuan solusi. 
Jurnal Pseudocode, Volume VI Nomor 1, Februari 2019, ISSN 2355-5920, e-ISSN 2655-1845 www.ejournal.unib.ac.id/index.php/pseudocode

\section{B. Saran}

Dikarenakan ilmu pengetahuan terus berkembang dan ditemukannya hal-hal baru maka basis pengetahuan dan basis aturan sistem pendukung keputusan ini perlu diupdate atau ditambah, sehingga data-data yang ada menjadi lebih lengkap dan akurat, interface (tampilan) sistem yang dibangun masih tampak sederhana, sehingga dapat dikembangkan lebih menarik dengan dilengkapi multimedia (suara dan gambar) maupun animasi.

\section{REFERENSI}

[1] Putri S Baby, Kartika Lindawati, 2017 “ Pengaruh Kualitas Pengguna Perspektif Dokter Rumah Sakit Hermina Bogor "Fakultas Universitas Islam Attahiriyah.

[2] Relita Buaton dan Raodah,2015 “ Sistem Pendukung Keputusan, Jakarta.

[3] Renggo Purnomo. 2013 “ Penerapan Tenaga Medis Perawatan dalam Mneingkatkan Kesehatan Masyarakat di RSUD Aji Batara Agung Dewa Sakti Kecamatan Samoja Kabupaten Kutai Karta Negara, ejournal Adminstrasi Negara, Volume I Nomor 2, Jakarta.

[4] Undang-Undang no. 24 Tahun 2011 Pasal 7 ayat 1, "BPJS".

[5] Frieyadi, 2016 “ Penerapan Metode Simple Additve Wight (SAW) dalam Sistem Pendukung Keputusan Promosi Kenaikan Jabatan Promosi Kenaikan Pangkat, Pilar Nusa Mandiri, AMIK BSI, Jakarta. 